Acta vet. scand. $1967,8,157-175$.

From the Department of Physiology, Veterinary College of Norway, Oslo.

\title{
FATE OF INGESTED HISTAMINE IN SHEEP
}

\section{DISAPPEARANCE FROM THE RUMEN*)}

By

Ø. V. Sjaastad

Many foodstuffs consumed by domestic animals contain histamine (Fowler 1962; Macpherson 1962; Stormorken \& Sjaastad 1962). In silage, the concentration of histamine is usually high (Macpherson; Stormorken \& Sjaastad) and values as high as $5.5 \mathrm{mg}$ histamine diphosphate/g dry weight of silage have been found (Eliassen et al., unpublished). Following administration of large amounts of readily fermentable carbohydrates by mouth, high concentrations of histamine are found in the rumen (Dain et al. 1955, Sanford 1963). In vitro addition of $\mathrm{L}$-histidine to sumen contents has been found to cause a rapid formation of histamine (Sjaastad 1967).

Little is known about the fate of histamine ingested with the food by sheep or formed in the reticulo-rumen by decarboxylation of histidine. The stability of histamine in rumen contents has apparently not been examined. Dougherty \& Cello (1949) observed hyperpnoea when histamine solution was sprayed on the dorsal wall of rumen of sheep, taking this as an indication of rapid absorption of histamine from the rumen. Inconsistent with this observation, Shinozaki (1957) was not able to demonstrate any disappearance of histamine from a rumen pouch. It should be mentioned, however, that the urine was not examined for histamine metabolites. Furthermore, the normality of rumen pouches has been questioned.

*) This work was financially supported by the Agricultural Research Council of Norway. I greatly appreciate the skilful technical assistance of Miss Liv Burum. 
In a previous paper (Sjacstad) it was demonstrated that even after ingestion of silage containing large amounts of histamine, the biological activity disappeared from reticulo-rumen within 3 - 6 hrs. The object of the present work was to study the mechanisms of disappearance.

\section{METHODS}

Animals and feeding. Adult sheep of the Dala breed, 8 males and 3 females, were studied. The animals were kept indoors in individual cages and fed twice daily, at 7 a.m. and 3 p.m. One meal consisted of hay of good quality $(0.5-0.6 \mathrm{~kg})$, the other one of hay $(0.4-0.5 \mathrm{~kg})$ and concentrates (ab. $0.3 \mathrm{~kg}$ ). The food was usually consumed within $1 / 2 \mathrm{hr}$. Any residual food at this time was removed. Water was freely available during the experiments.

Histamine loading was occasionally done by substituting silage for hay or concentrates. In most experiments, however, histamine diphosphate $(0.1-10.0 \mathrm{~g})$ was dissolved in $300 \mathrm{ml}$ of tap water and administered by a stomach tube or through a permanent rumen fistula. C14-labelled histamine $(40-100 \mu$ Curie $)$ was given together with carrier-histamine. In one experiment $\mathrm{C}^{14-h i s t a m i n e}$ was given subcutaneously.

$\mathrm{N}$-acetylhistamine, either alone or together with histamine diphosphate, was dissolved and administered as described above.

Sampling. Rumen contents were aspirated according to Krogh (1959). To obtain a fairly even distribution of histamine in the rumen, the first sample was taken $1 / 2 \mathrm{hr}$. after consumption of silage or administration of histamine. Even at this time histamine was apparently not evenly distributed within the rumen in some experiments (see below)". Abomasal contents were obtained through a permanent abomasal cannula.

Rumen liquor was prepared by centrifuging rumen contents at $3000 \times \mathrm{g}$ for $2 \mathrm{~min}$. at room temperature immediately after aspiration.

\section{Determination of free and conjugated histamine in rumen liquor}

Free histamine. Two different methods were used:

1. Pilot experiments showed that rumen liquor might amount to $2-3 \%$ of the fluid volume in the organ bath without interfering with the biological estimation of histamine. Hence, in experiments where all samples were expected to contain histamine in concentrations necessitating addition of only small volumes of rumen liquor to the organ bath, histamine assays were performed directly after dilution with Tyrode's solution to obtain suitable concentrations for the assay. As histamine is both formed (Sjaastad 1967) and inactivated (see below) by rumen contents, stress was laid on performing the histamine assay, as soon as possible after aspiration, and usually this was accomplished within $10 \mathrm{~min}$.

2. Ion-exchange chromatography, according to the principles outlined 
by Bergstrøm \& Hansson (1951) was used for the extraction of histamine from rumen liquor $(25 \mathrm{ml})$ in experiments where some of the samples were expected to be low in histamine concentration. This method involves adsorption of histamine on Amberlite IRC-50 columns, followed by elution with $\mathrm{HCl}$. The procedure is described in details elsewhere (Sjaastad). The average recovery of histamine diphosphate $(5-20 \mu \mathrm{g} / 25 \mathrm{ml})$ added to rumen liquor was $81.1 \pm 5.9(\mathrm{~s}) \%$ (35 expts.).

Conjugated histamine. Conjugated histamine (believed to be identical to N-acetylhistamine, Tabor \& Mosettig 1949) was determined as the increase in free histamine occurring upon acid hydrolysis (Anrep et al. 1944). $\mathrm{N}-\mathrm{HCl}$ in amounts sufficient to give a $\mathrm{pH}$ of about 2 was added to $25 \mathrm{ml}$ aliquots of rumen liquor immediately after centrifugation. The rumen liquor was evaporated to $2-3 \mathrm{ml}$ ex vacuo. The residues were quantitatively transferred to conical flasks with $6+5+4 \mathrm{ml}$ conc. $\mathrm{HCl}$ and boiled under reflux for $2 \mathrm{hrs}$. The hydrolyzates were evaporated to complete dryness ex vacuo and the residues dissolved in $60-80 \mathrm{ml}$ of distilled $\mathrm{H}_{2} \mathrm{O}$. After adjustment of the $\mathrm{pH}$ to 6.5 (Radiometer, Copenhagen), the mixtures were centrifuged at $3000 \times \mathrm{g}$ for $10 \mathrm{~min}$. The volumes of the supernatant fluids were made up to $100 \mathrm{ml}$ by adding distilled $\mathrm{H}_{2} \mathrm{O}$, and histamine extracted by passage through Amberlite IRC-50 columns $(80 \times 10 \mathrm{~mm})$. Thereafter the procedure was as described for the determination of free histamine in rumen liquor (Sjaastad). The recovery of $\mathrm{N}$-acetylhistamine added to rumen liquor $(10-50 \mu \mathrm{g} / 25 \mathrm{ml}, 18$ expts.) was $75.8 \pm 7.7$ (s) $\%$.

In 8 preliminary experiments the rumen liquor was precipitated with two volumes of acetone prior to evaporation as recommended by Dunér \& Pernow (1956) for the estimation of conjugated histamine in human urine. The recovery of $\mathrm{N}$-acetylhistamine $(10-50 \mu \mathrm{g} / 25 \mathrm{ml})$ added to rumen liquor treated in this way was low and variable $(41.3 \pm 15.8(\mathrm{~s}) \%)$. This procedure was therefore not further used.

Histamine determinations were carried out on isolated guinea-pig ileum, suspended in an organ bath $(6 \mathrm{ml})$ containing Tyrode's solution $\left(37^{\circ} \mathrm{C}\right)$ with atropine $(0.05 \mu \mathrm{g} / \mathrm{ml})$ and glucose $(1 \mathrm{~g} / \mathrm{l})$. Tests were made every 55 sec. and the determination of the unknown was done by bracketing between standards. Histamine values given in this paper are calculated as the diphosphate and are not corrected for losses. In most experiments coded samples were used.

Radioactive measurements. For the determination of radioactivity $100 \mu l$ rumen liquor and a small drop of detergent (to reduce surface tension) were plated and left at $60-70^{\circ} \mathrm{C}$ until completely dry. The samples were counted on a Beckman flowcounter (Lowbeta II) for at least 200 counts and never for less than $3 \mathrm{~min}$. The background was about 1.5 c.p.m. and the geometrical efficiency of the counter was approximately $27 \%$. The figures given for radioactivity are corrected for background. The plates were occasionally weighed before and after plating. The weight was of an order which did not cause any substantial selfabsorption. 


\section{In vitro studies}

Rumen contents aspirated at different intervals after ingestion of histamine, were incubated under anaerobic conditions at $38^{\circ} \mathrm{C}$ for variable intervals of time. Care was taken to start the incubation as soon as possible after aspiration. Samples of the incubates were removed at noted intervals and free and/or conjugated histamine determined. Two slightly different methods for incubation were used: 1) Erlenmeyer flasks $(50-250 \mathrm{ml})$ containing rumen contents (25$200 \mathrm{ml}$ ) were attached to a shaking device of a water thermostat. $\mathrm{N}_{2}$ was fed through the incubation flasks during the entire incubation period. In order to reduce the washing out of fermentation gases, $\mathrm{N}_{2}$ was not alowed to bubble through the rumen contents. Since $\mathrm{CO}_{2}$ is normally present in the rumen, a gas mixture of $5 \% \mathrm{CO}_{2}$ and $95 \% \mathrm{~N}_{2}$ was used in some preliminary experiments. This did not change the inactivation to any detectable extent. 2) It was conceivable that the washing out of fermentation gases which certainly occurred in method 1 might affect the inactivation of histamine. By method 2 this was considered to be avoided: Two narrow-bore metal cannulas were inserted through the rubber stopper of the incubation flasks. $\mathrm{N}_{2}$ was fed through the cannulas to wash out the air. After gassing for approximately $2 \mathrm{~min}$. one of the cannulas was closed, the other being left open so that fermentation gases might escape. On account of the outward flow of these gases air did probably not diffuse into the incubation flasks to any considerable extent during experiments of short duration. If aliquots of rumen contents were removed during the incubation period, gassing was performed anew.

\section{Comparison between the disappearance from rumen of histamine and an inert marker (PEG)}

The disappearance of histamine from the rumen was compared with that of polyethylene glycol (PEG), a substance which is neither destroyed by rumen bacteria nor absorbed by the ruminal epithelium (Sperber et al. 1953). PEG was determined according to Hydèn (1956).

PEG (10 g) and histamine were dissolved in $300 \mathrm{ml}$ of tap water, and administered by a stomach tube or through a permanent rumen fistula. Samples of rumen contents were aspirated at noted intervals and the concentration of $\mathrm{PEG}$ and histamine in rumen liquor determined. Extrapolation was made to obtain zero time concentration of PEG from which the rumen fluid volume at this time could be calculated. When biological active histamine no longer could be demonstrated in the rumen, another dose of PEG ( $5 \mathrm{~g})$ was administered and the concentration determined each $30 \mathrm{~min}$. for another $2 \mathrm{hrs}$. From the increment in the concentration of PEG caused by the second dose, the rumen fluid volume at the "disappearance time" of histamine was approximated. The amount of PEG which had disappeared from reticulo-rumen between zero-time and the time when histamine activity no longer could be detected was then calculated. 


\section{MATERIALS}

Histamine diphosphate (HiDP) and $\mathrm{N}$-acetylhistamine from Nutritional Biochemicals Corp., Gleveland, Ohio was used.

C14-histamine-dihydrochloride (labelled in the ring-2 position) was purchased from the Radiochemical Centre, Amersham. The specific activities in the two batches used were 116 and $166 \mu \mathrm{Curie} / \mathrm{mg}$.

Polyethylene glycol (PEG) with average molecular weight of 4000 was obtained from British Drug Houses Ltd.

Ion-exchange resin. Ion-exchange was performed with Amberlite IRC-50, Standard Grade. Batches of the resin were prepared according to Bergstrøm \& Hansson (1951).

\section{RESULTS}

Comparison between the in vivo and the in vitro disappearance of histamine in rumen contents after oral loading

In 5 experiments performed in 2 sheep, the in vivo and in vitro disappearance of histamine were compared after oral administration of HiDP. The rumen contents used for the in vitro experiments were aspirated $1 / 2 \mathrm{hr}$. after administration of histamine. The results of a typical experiment are given in Fig. 1. The

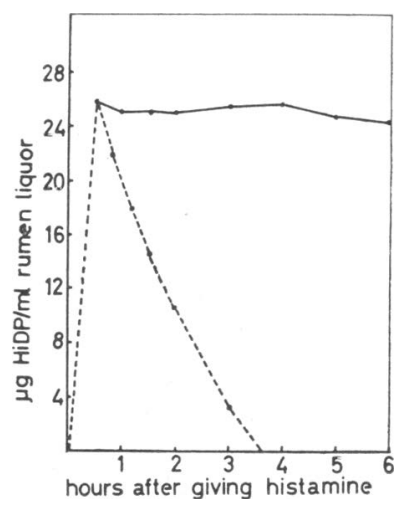

Figure 1. The in vivo (-_..--) and the in vitro (disappearance of histamine in rumen contents after giving $200 \mathrm{mg}$ histamine diphosphate by mouth about 5 hrs. after feeding hay.

discrepancy between the in vivo and in vitro disappearance of histamine from rumen contents was evident (Fig. 1). The average interval between administration of histamine and the time when histamine activity no longer could be detected in vivo was 4 hrs. (Table 1). During this period the concentration of histamine did not change considerably in vitro (Table 1 ). 
Table 1. The disappearance of histamine from rumen contents in vivo and in vitro. Histamine administered orally $4-6 \mathrm{hrs}$. after feeding hay. The rumen contents used for the in vitro experiments were aspirated $1 / 2 \mathrm{hr}$. after giving histamine. Histamine assayed by method 1.

\begin{tabular}{|c|c|c|c|c|}
\hline $\begin{array}{c}\text { Sheep } \\
\text { no. }\end{array}$ & $\begin{array}{c}\text { Dose of } \\
\text { histamine } \\
\text { admi- } \\
\text { nistered } \\
\text { (mg HiDP) }\end{array}$ & $\begin{array}{c}\text { "Disappearance } \\
\text { time" of } \\
\text { histamine } \\
\text { in vivo } \\
\text { (hrs.) }\end{array}$ & $\begin{array}{c}\text { Histamine } \\
\text { concentration } \\
1 / 2 \mathrm{hr} \text {. after } \\
\text { administration } \\
(\mu \mathrm{g} \mathrm{HiDP} / \mathrm{ml})\end{array}$ & $\begin{array}{l}\text { In vitro concen- } \\
\text { tration of hist- } \\
\text { amine ( } \mu \mathrm{g} \text { HiDP/ } \\
\text { ml) at the in vivo } \\
\text { "disappearance } \\
\text { time" of } \\
\text { histamine } \\
(\mu \mathrm{g} \mathrm{HiDP} / \mathrm{ml})\end{array}$ \\
\hline 1 & 200 & 4 & 46.5 & 46.0 \\
\hline 1 & 200 & 4 & 43.2 & 40.1 \\
\hline 1 & 400 & 4 & 79.3 & 76.8 \\
\hline 2 & 200 & $3^{1 / 2}$ & 39.3 & 36.2 \\
\hline 2 & 400 & $41 / 2$ & 59.0 & 57.8 \\
\hline
\end{tabular}

Also when histamine was ingested as a component of silage, the disappearance of histamine in vivo far exceeded that in vitro (Table 2). But whereas the concentration of histamine never increased significantly by incubation of rumen contents aspirated

T a b l e 2. In vivo and in vitro disappearance of histamine in rumen contents after feeding silage. The in vitro samples were aspirated $1 / 2 \mathrm{hr}$.

after the feeding had started. Histamine assayed by method 1.

\begin{tabular}{cccc}
\hline $\begin{array}{c}\text { Sheep } \\
\text { no. }\end{array}$ & $\begin{array}{c}\text { "Disappearance } \\
\text { time" of } \\
\text { histamine } \\
\text { in vivo } \\
\text { (hrs.) }\end{array}$ & $\begin{array}{c}\text { Initial } \\
\text { concentration } \\
\text { of histamine } \\
\text { in vitro } \\
\text { ( } \mu \mathrm{g} \mathrm{HiDP} / \mathrm{ml})\end{array}$ & $\begin{array}{c}\text { In vitro concen- } \\
\text { tration of } \\
\text { histamine at the } \\
\text { in vivo "disappe- } \\
\text { arance time" } \\
(\mu \mathrm{g} \mathrm{HiDP} / \mathrm{ml})\end{array}$ \\
\hline 1 & $31 / 2$ & 13.8 & 24.5 \\
2 & $31 / 2$ & 12.1 & 15.3 \\
2 & $41 / 2$ & 17.0 & 14.9 \\
2 & $31 / 2$ & 7.4 & 6.5 \\
3 & 4 & 39.2 & 34.2 \\
4 & $31 / 2$ & 16.0 & 15.0 \\
\hline
\end{tabular}

subsequent to administration of histamine, such an increase occasionally took place by incubation of rumen contents aspirated after feeding silage. In one experiment the in vitro concentration of histamine increased to about two times the value found just 


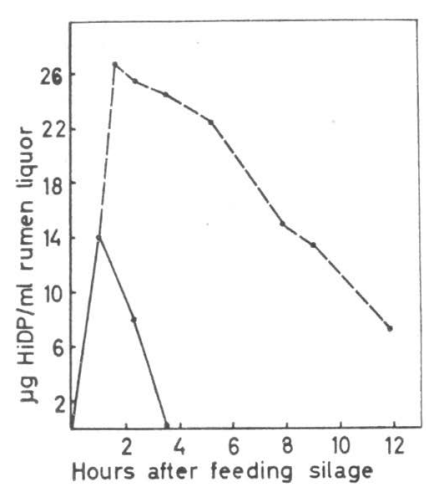

a

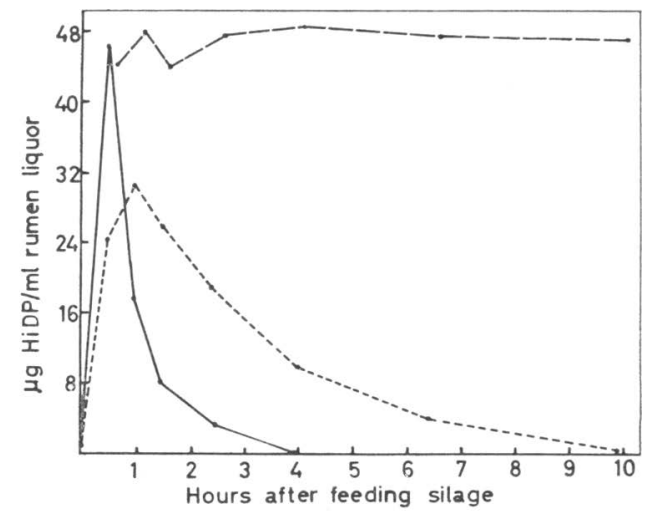

$\mathrm{b}$

Figures 2 a a n 2 b. The disappearance of histamine in vivo $(-)$ and in vitro (- - ${ }^{-}$) after feeding silage. In Fig. $2 \mathrm{~b}$ is also shown the disappearance of histamine from the abomasum (- . - . . Histamine determined by method 1.

after aspiration (Fig. 2a). After the initial rise the concentration usually decreased. The decrease was, however, slow compared with that in vivo. In vivo the highest concentration of histamine was always found in the first sample after feeding silage. The results of two typical experiments are demonstrated in Figs. 2a and $2 \mathrm{~b}$.

In 4 experiments the in vitro disappearance of histamine in rumen contents aspirated $1 / 2 \mathrm{hr}$. and $3 \frac{1 / 2}{\mathrm{hrs}}$. after feeding silage, was compared (Table 3 ). When rumen contents, aspirated after feeding silage rich in histamine, were incubated for periods corresponding to the in vivo "disappearance time" of histamine, the changes in histamine concentration in vitro were too small to be regarded as significant (Table 3, expt. nos. 1 and 2). In rumen contents aspirated $3 \frac{1 / 2}{h} \mathrm{hrs}$. after feeding silage poor in histamine, on the other hand, a large percentage decrease in histamine concentration took place during incubation for corresponding intervals of time (Table 3 , expt. nos. 3 and 4 ). In rumen contents aspirated $1 / 2 \mathrm{hr}$. after feeding, the histamine concentration decreased only slightly during the same interval of time (Table 3, expt. nos. 3 and 4). Furthermore, undetectable in vitro levels of histamine were reached within shorter periods of time in rumen contents aspirated $3 \frac{1}{2} \mathrm{hrs}$. after feeding than in rumen contents aspirated $1 / 2 \mathrm{hr}$. after feeding (Table 3 ). 
Ta b l e 3. Comparison between the disappearance in vitro of histamine in rumen contents aspirated $1 / 2$ and $3 \frac{1}{2} \mathrm{hrs}$. after feeding silage. Histamine determined by method 1. Incubation method 1. To the rumen samples aspirated $3 \frac{1 / 2}{1 / 2}$ hrs. after feeding, histamine was added in amounts giving about the same initial concentration as in rumen contents aspirated $1 / 2 \mathrm{hr}$. after feeding.

\begin{tabular}{|c|c|c|c|c|c|}
\hline \multirow[b]{2}{*}{$\begin{array}{c}\text { Exp. } \\
\text { no. }\end{array}$} & \multirow[b]{2}{*}{$\begin{array}{l}\text { Concentration } \\
\text { of histamine } \\
\text { in vivo } 1 / \mathrm{h} \mathrm{hr} \text {. } \\
\text { after feeding } \\
(\mu \mathrm{g} \mathrm{HiDP} / \mathrm{ml})\end{array}$} & \multicolumn{2}{|c|}{$\begin{array}{l}\text { Histamine left in vitro } \\
\text { after incubation for periods } \\
\text { corresponding to the in vivo } \\
\text { "disappearance time,' } \\
(\mu \mathrm{g} \mathrm{HiDP} / \mathrm{ml})\end{array}$} & \multicolumn{2}{|c|}{$\begin{array}{c}\text { Interval of time before the } \\
\text { in vitro samples had reached } \\
\text { undetectable levels } \\
\text { (hrs.) }\end{array}$} \\
\hline & & $\begin{array}{l}\text { In rumen } \\
\text { contents } \\
\text { aspirated } \\
31 / 2 \text { hrs. after } \\
\text { feeding silage }\end{array}$ & $\begin{array}{l}\text { In rumen } \\
\text { contents } \\
\text { aspirated } \\
1 / 2 \text { hr. after } \\
\text { feeding silage }\end{array}$ & $\begin{array}{l}\text { In rumen } \\
\text { contents } \\
\text { aspirated } \\
31 / 2 \text { hrs. after } \\
\text { feeding silage }\end{array}$ & $\begin{array}{l}\text { In rumen } \\
\text { contents } \\
\text { aspirated } \\
1 / 2 \text { hr. after } \\
\text { feeding silage }\end{array}$ \\
\hline 1 & 35.0 & 30.6 & 34.9 & 28 & 46 \\
\hline 2 & 45.5 & 39.5 & 46.3 & 30 & 48 \\
\hline 3 & 7.5 & 4.4 & 6.5 & $81 / 2$ & $12^{1 / 2}$ \\
\hline 4 & 8.9 & 5.2 & 8.8 & 10 & $17^{1 / 2}$ \\
\hline
\end{tabular}

Relationship between feeding and inactivation of histamine in rumen contents

The results presented in Table 3 indicated that rumen contents inactivated histamine at a slow rate and that the inactivation was related to the time of feeding. It is difficult, however, to estimate accurately small changes in histamine inactivation when high concentrations of histamine are initially present. Furthermore, after feeding silage, the in vitro rise in histamine concentration occasionally observed in the first part of the incubation period (Fig. 2a) impeded the interpretation as to the relationship between histamine inactivation and time of feeding. It therefore seemed advisable to examine the histamine inactivation in vitro by adding small amounts to rumen contents aspirated at different intervals after feeding a diet providing low concentrations of histamine in vivo.

Fig. 3 demonstrates the in vitro inactivation of histamine in rumen contents aspirated at different intervals after feeding hay. The most rapid decrease in histamine concentration was found in rumen contents aspirated about $3 \mathrm{hrs}$. after feeding (Fig. 3). In rumen contents aspirated shortly after feeding the concentration of histamine often increased during the incubation period. In 8 experiments performed in 4 sheep the histamine 


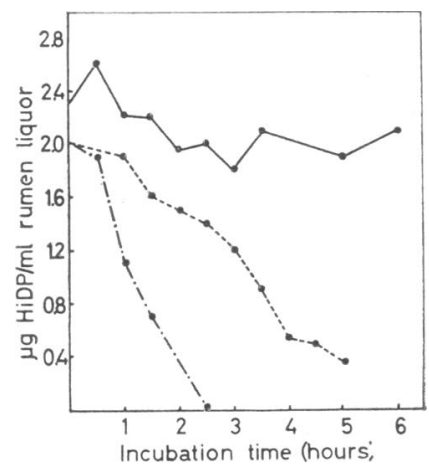

F i g u r e 3. The in vitro disappearance of histamine in rumen contents aspirated $3 / 4(-\longrightarrow), 31 / 2(-.-.-)$ ) and $17(-\ldots . .-)$ hrs. after feeding hay. Amount of histamine added: $2 \mu \mathrm{g}$ histamine diphosphate $/ \mathrm{ml}$. Histamine determined by method 1 . Note the initial histamine value in rumen contents aspirated $3 / 4 \mathrm{hr}$. after feeding (about $2.3 \mu \mathrm{g} / \mathrm{ml}$ ).

inactivation in rumen contents aspirated about $3 \mathrm{hrs}$. after feeding was examined. In these experiments $\mathrm{pH}$ varied between 6.6 and 6.9. The relationship between incubation time and histamine inactivation was almost linear when mean values were used (Fig. 4). If the decrease in histamine concentration from $0-2$ hrs. was used for the calculation, a histamine inactivation of $0.57 \pm 0.21 \mu \mathrm{g} \mathrm{HiDP} / \mathrm{ml}$ rumen contents/hr. was found.

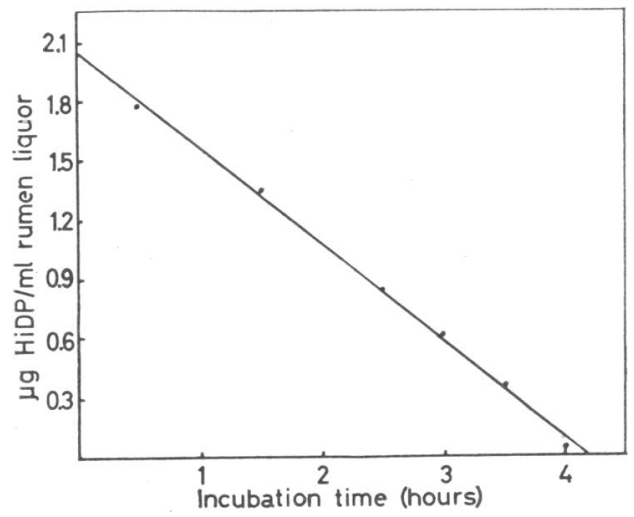

$\mathrm{Fig}$ u re 4. In vitro inactivation of histamine added to rumen contents $(2 \mu \mathrm{g}$ histamine diphosphate $/ \mathrm{ml})$ aspirated $3 \mathrm{hrs}$. after feeding hay. The curve represents mean values of 5 experiments. Incubation method 1. Histamine determined by method 2. 
Comparison of the disappearance of histamine and polyethylene glycol from the rumen

In 8 experiments histamine and PEG were given by mouth about $5 \mathrm{hrs}$. after feeding. The difference between the rates of disappearance from the rumen of the two substances was evident (Fig. 5).

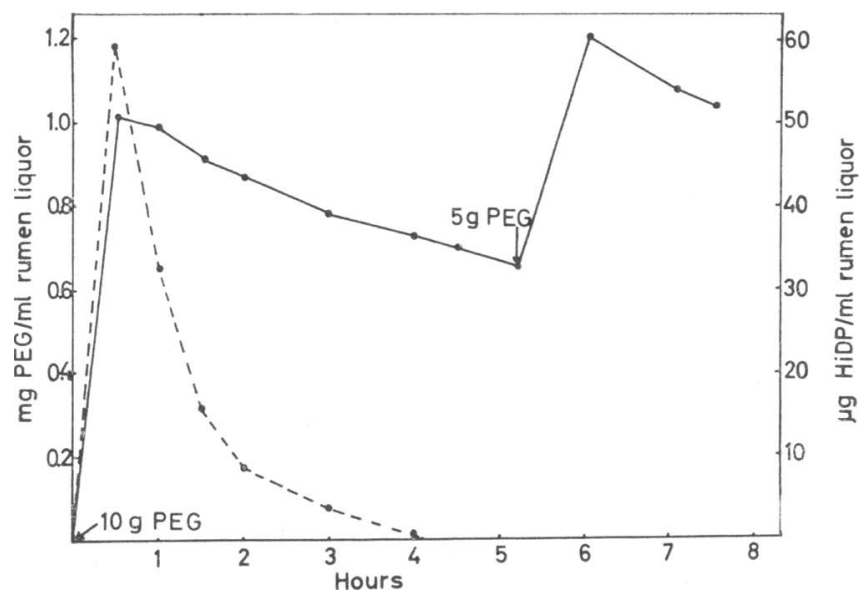

Figure 5. Comparison between the disappearance of histamine (-...-) and PEG (- from rumen. Ten $g$ of PEG and 400 mg histamine diphosphate given at zero-time. The second dose of PEG given to determine the rumen fluid volume at the time when the

biological activity of histamine had disappeared from rumen.

On an average, $65 \pm 7 \%$ of the amount of PEG administered at zero time remained in reticulo-rumen at the time when histamine activity no longer could be demonstrated in vivo. Since the histamine concentration decreased faster than the concentration of PEG, less than $35 \%$ of the histamine administered at zero time had left reticulo-rumen unchanged through the reticuloomasal orifice during this period of time.

Occasionally PEG was not evenly distributed in the rumen at the time for the first rumen sample $(1 / 2 \mathrm{hr}$.). This was usually characterized by a large decrease in the PEG concentration from the first to the second sample ( $1 \mathrm{hr}$.). Furthermore, the PEG concentration varied widely in rumen samples aspirated from different parts of the rumen $1 / 2 \mathrm{hr}$. after administration of PEG. In one experiment the concentration of $P E G$ ranged between $1.40-1.95 \mathrm{mg} / \mathrm{ml}$. When more than $1 / 2 \mathrm{hr}$. had elapsed since 
administration of PEG, good agreement was found between different rumen samples. When PEG was unevenly distributed after $1 / 2 \mathrm{hr}$., the rumen volumes at zero-time and/or when histamine no longer could be detected in vivo, were calculated from the main part of the curves, excluding values at $1 / 2 \mathrm{hr}$.

When histamine was administered orally, the histamine concentration was also high in the abomasum (Fig. 2b). Histamine remained at detectable levels for a longer period in abomasum than in rumen (Fig. 2b).

Formation of conjugated histamine in rumen contents in vitro

By the method used in the present study small amounts of conjugated histamine were difficult to determine accurately in the presence of high concentration of free histamine. Hence, rumen contents to which histamine had been added $(10 \mu \mathrm{g} / \mathrm{ml})$ were incubated until free histamine could no longer be detected by direct assay. Prior to incubation neither free nor conjugated histamine could be demonstrated. Conjugation of histamine was demonstrated in the 5 sheep examined (Table 4). The amounts of

T a b l e 4. Formation of conjugated histamine in rumen contents in vitro. Initial concentration: $10 \mu \mathrm{g} \mathrm{HiDP} / \mathrm{ml}$. Rumen contents aspirated $3-4 \mathrm{hrs}$. after feeding hay. Incubation periods $10-25 \mathrm{hrs}$. Both free and conjugated histamine determined by ion-exchange technique.

\begin{tabular}{|c|c|c|c|c|c|}
\hline \multirow{2}{*}{$\begin{array}{l}\text { Exp. } \\
\text { no. }\end{array}$} & \multirow{2}{*}{$\begin{array}{c}\text { Sheep } \\
\text { no. }\end{array}$} & \multirow{2}{*}{$\begin{array}{l}\text { Treat- } \\
\text { ment }\end{array}$} & \multicolumn{2}{|c|}{$\begin{array}{l}\text { Histamine left after } \\
\text { incubation } \\
\text { (as } \mu \mathrm{g} \mathrm{HiDP} / \mathrm{ml} \text { ) }\end{array}$} & \multirow{2}{*}{$\begin{array}{c}\text { Conjugated } \\
\text { histamine as per } \\
\text { cent of amount } \\
\text { added }\end{array}$} \\
\hline & & & Free & Conjugated & \\
\hline 1 & 2 & - $\left.^{\star}\right)$ & 0.06 & 0.27 & 2.7 \\
\hline 2 & ” & - & 0.09 & 0.12 & 1.2 \\
\hline $\mathbf{3 a}$ & ” & - & 0.02 & 0.07 & 0.7 \\
\hline $3 \mathbf{b}$ & , & acetyl-CoA & 0.03 & 0.06 & 0.6 \\
\hline $4 a$ & ” & - & 0.02 & 0.07 & 0.7 \\
\hline $4 b$ & , & acetyl-CoA & 0.04 & 0.05 & 0.5 \\
\hline $5 \mathbf{a}$ & 7 & - & 0.04 & 0.15 & 1.5 \\
\hline $5 b$ & , & acetyl-CoA & 0.05 & 0.42 & 4.2 \\
\hline $6 a$ & 9 & - & 0.11 & 0.84 & 8.4 \\
\hline $6 b$ & ” & 一 & 0.12 & 0.79 & 7.9 \\
\hline 7 & ” & - & 0.09 & 0.15 & 1.5 \\
\hline 8 & 4 & - & 0.03 & 0.09 & 0.9 \\
\hline $9 a$ & 5 & - & 0.08 & 0.07 & 0.7 \\
\hline $9 b$ & ” & - & 0.07 & 0.06 & 0.6 \\
\hline
\end{tabular}


conjugated histamine formed were variable and were not increased by addition of acetyl-CoA (Table 4).

\section{Disappearance of $\mathrm{N}$-acetylhistamine from the rumen}

Formation of conjugated histamine in rumen contents of the order indicated by the in vitro experiments (Table 4) would be impossible to detect in vivo, unless conjugated histamine disappears from the rumen at a slower rate than free histamine. The disappearance of $\mathrm{N}$-acetylhistamine and HiDP from rumen was therefore compared after giving the two substances by mouth in quantities corresponding to the same amounts of histamine base. $\mathrm{N}$-acetylhistamine disappeared more slowly from the rumen than

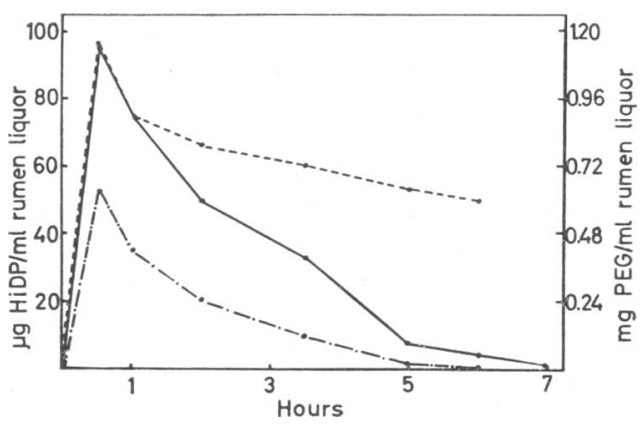

F ig u re 6. Disappearance of histamine (-- - - - ), N-acetylhistamine (stration. Amounts given: $10 \mathrm{~g}$ PEG, $400 \mathrm{mg}$ histamine diphosphate and $200 \mathrm{mg} \mathrm{N}$-acetylhistamine. Free histamine determined by method 2.

free histamine (Fig. 6). N-acetylhistamine on the other hand, disappeared from the rumen at a rate far exceeding that of PEG (Fig. 6). Similar results as shown in Fig. 6 were found in two other experiments.

Formation of conjugated histamine in rumen contents in vivo

When large amounts of histamine were given by mouth (4 expts.), conjugated histamine in small quantities was demonstrated in the rumen when free histamine had reached low levels. The results of one experiment are shown in Fig. 7.

Stability of $\mathrm{N}$-acetylhistamine in rumen contents in vitro

The fast disappearance of $\mathrm{N}$-acetylhistamine from the rumen (Fig. 6) might be due to degradation of this substance. How- 


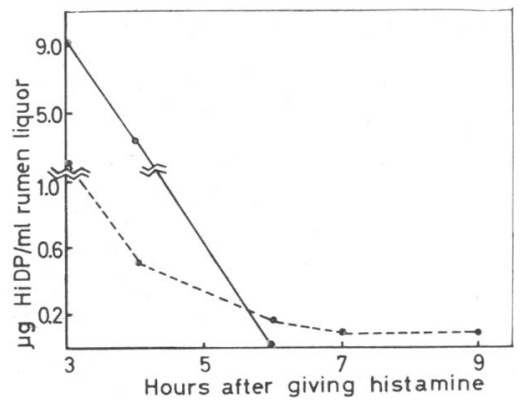

F i g u r e 7. Occurrence of conjugated histamine (- . . . - ) in rumen contents in vivo after giving $800 \mathrm{mg}$ histamine diphosphate by mouth. Free histamine (—) determined by method 2. Prior to histamine loading conjugated histamine was not demonstrated in the rumen contents.

ever, when $\mathrm{N}$-acetylhistamine was added to rumen contents, $70.4 \pm 9.8 \%$ was left after incubation for $2 \mathrm{hrs}$. This was not significantly lower than the recovery of added $\mathrm{N}$-acetylhistamine in unincubated rumen contents $(75.8 \pm 7.7 \%, \mathrm{P}>0.05)$.

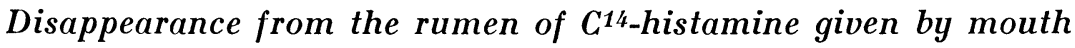

In 8 experiments $\mathrm{C}^{14}$-histamine $(40-80 \mu \mathrm{Curie})$ was given by mouth together with unlabelled histamine and in some experiments also PEG. The biological activity invariably disappeared faster from the rumen than did the radioactivity (e.g. Figs. 8 and 9). The radioactivity, on the other hand, disappeared faster than PEG. The rate of disappearance of the radioactivity varied considerably between experiments. Some radioactivity remained in the rumen even after $24 \mathrm{hrs}$.

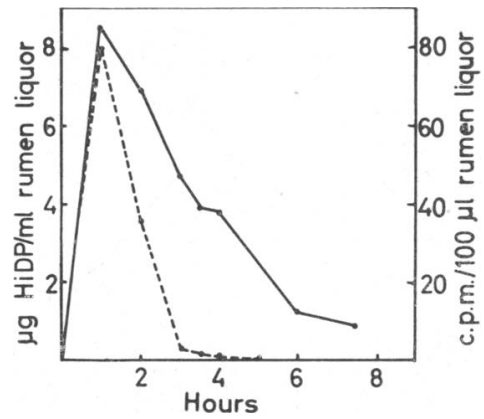

Fig u re 8. Disappearance of biological activity (-_._.--) and radioactivity (-) from rumen. Amounts given: $200 \mathrm{mg}$ histamine diphosphate and $60 \mu$ Curie C14-histamine. 
Occurrence of $C^{14-h i s t a m i n e ~ i n ~ t h e ~ r u m e n ~ a f t e r ~ s u b c u t a n e o u s ~}$ injection

Possibly histamine, if absorbed from the digestive tract, might be recirculated into the digestive tract after being inactivated in the tissues. A recirculation of this kind might partly explain the different disappearance rates of biological activity and radioactivity as shown in Figs. 8 and 9. In one experiment $\mathrm{C}^{14}$-hista-

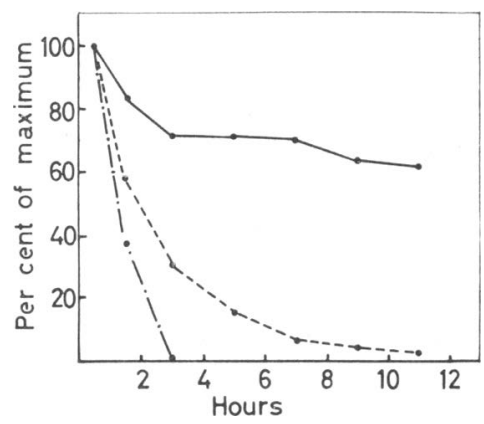

F i g u re 9. Disappearance of biological activity (- $--\longrightarrow)$, radioactivity (-...-.) and PEG (_ministration of these substances. Amounts given: $200 \mathrm{mg}$ histamine diphosphate, $50 \mu$ Curie C14-histamine and $10 \mathrm{~g}$ PEG. Maximum values were: Histamine: $17.2 \mathrm{lg} / \mathrm{ml}$, radioactivity: 3170 c.p.m./ml, PEG: $1.99 \mathrm{mg} / \mathrm{ml}$.

mine was therefore injected subcutaneously and the rumen contents examined for radioactivity the following $24 \mathrm{hrs}$. Radioactivity above background was demonstrated (Fig. 10). The rumen volume was not recorded in this experiment but was in other experiments in this sheep found to be about $10 \mathrm{l}$. Assuming a rumen volume of this size, the peak radioactivity (3.38 c.p.m./

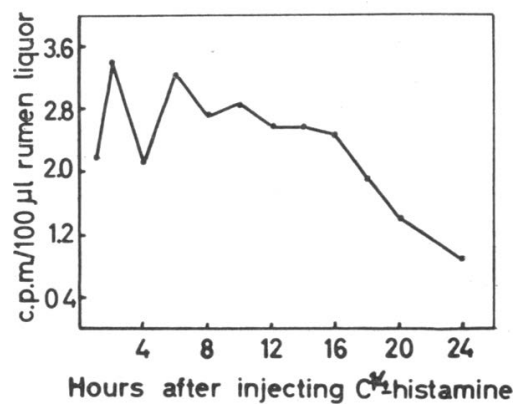

$\mathrm{Fig}$ u r e 10 . Occurrence of radioactivity in rumen after subcutaneous injection of C14-histamine (100 $\mu$ Curie). 
$100 \mu \mathrm{l}$ rumen liquor) should correspond to a total radioactivity of about $3.4 \times 10^{5}$ c.p.m. in the rumen compared with $5.9 \times 10^{7}$ c.p.m. in the administered dose. It should be noted that the radioactivity decreased more rapidly from the rumen when given by mouth (Figs. 8 and 9 ) than when injected subcutaneously (Fig. 10).

\section{DISCUSSION}

When histamine was given by mouth, the biological activity disappeared from the rumen at a rate far exceeding that of an inert marker (Fig. 5). Furthermore, little or no inactivation of histamine was demonstrated in rumen contents in vitro (e.g. Fig. 3). This suggested that the rapid disappearance of histamine from the rumen was mainly due to absorption of unchanged histamine by the rumen epithelium. However, when $\mathrm{C}^{14}$-histamine was administered by mouth simultaneously with carrier-histamine, the radioactivity disappeared much slower from the rumen than the biological activity (Figs. 8 and 9). It was at first thought possible that this discrepancy might be due to flux into the rumen of histamine metabolites being formed in the tissues subsequent to absorption of free histamine. The low radioactivity observed in rumen after subcutaneous injection of $\mathrm{C}^{14}$-histamine (Fig. 10), did, however, not support this view. The discrepancy between the rates of disappearance of biological activity and radioactivity therefore seemed to be indicative of considerable inactivation of histamine in the rumen.

This study offers no basis for explaining the apparently contradictory results of the in vivo and the in vitro experiments as far as inactivation of histamine by rumen contents is concerned. The rate of histamine inactivation in vitro was fairly constant during incubation periods of $3-4 \mathrm{hrs}$. (Fig. 4). It is therefore not likely that accumulation of fermentation products should inhibit the inactivation of histamine in vitro substantially. The rumen contents used for the in vitro experiments were obviously partly fractionated by the aspiration procedure resulting in dry matter contents as low as $2-3 \%$. It is conceivable that the metabolic activity and the relative number of the different types of ruminal microorganisms in aspirated samples might be different from those in vivo. The difference between the disappearance rates of biological activity and radioactivity from the rumen might also 
be due to other factors than inactivation of histamine by rumen contents. This problem is being further studied.

After giving $\mathrm{C}^{14}$-histamine by mouth the radioactivity disappeared from the rumen at a rate exceeding that of PEG (Fig. 9). Possibly this might partly be due to absorption of free histamine from rumen. However, since the radioactivity decreased faster than the PEG concentration also when biological activity no longer could be demonstrated, the different disappearance rates of PEG and radioactivity might be entirely due to absorption of inactivation products of histamine. The isotope results in Figs. 8, 9 and 10 may indicate some difference in the rates of disappearance from the rumen between (1) histamine metabolites entering the organ from the blood stream and (2) free histamine introduced directly into the rumen. However, without control experiments with continuous intraruminal infusion of histamine and histamine metabolites no final conclusion can be drawn.

The interpretation of experiments on the relationship between time of feeding and inactivation of histamine by rumen contents in vitro was difficult since histamine probably is normally also formed in rumen contents (Sjaastad 1967). Reliable information on the real rate of inactivation might be obtained by utilizing substances known to inhibit L-histidine-decarboxylase in tissuepreparations.

$\mathrm{N}$-acetylhistamine disappeared rapidly from the rumen and no degradation by rumen contents was demonstrated in vitro. This indicated that $\mathrm{N}$-acetylhistamine was absorbed by the rumen epithelium. Conjugated histamine originating from histamine normally formed in the rumen might therefore be a source of conjugated histamine in the urine. The quantitative importance of this conjugation process is, however, difficult to evaluate since the conjugated histamine formed is probably simultaneously subjected to absorption.

\section{REFERENGES}

Anrep, G. V., M. S. Ayadi, G. S. Barsoum, J. R. Smith \& M. M. Talaat: The excretion of histamine in urine. J. Physiol. (Lond.) 1944, 103, 155-174.

Bergstrøm, S. \& G. Hansson: The use of Amberlite IRC-50 for the purification of adrenaline and histamine. Acta physiol. scand. 1951, 22, 87-92. 
Dain, J. A., A. L. Neal \& R. W. Dougherty: The occurrence of histamine and tyramine in rumen ingesta of experimentally over-fed sheep. J. Animal Sci. 1955, 14, 930—935.

Dougherty, R. W. \& R. M. Cello: Study of toxic factors in the ingesta of cows and sheep. Cornell Vet. 1949, 39, 403-413.

Dunér, H. \& B. Pernow: Urinary excretion of histamine in healthy human subjects. Scand. J. clin. Lab. Invest. 1956, 8, 296-303.

Fowler, H. D.: Histamine in grasses and clovers. Nature (Lond.) 1962, 193, 582-583.

Hydén, S.: A turbidimetric method for the determination of higher polyethylene glycols in biological materials. Ann. roy. agric. Coll. Sweden 1956, 22, 139-145.

$K r o g h, N .:$ Studies on alterations in the rumen fluid of sheep, especially concerning the microbial composition, when readily available carbohydrates are added to the food. 1 . Sucrose. Acta vet. scand. $1959,1,74-97$.

Macpherson, H. T.: Histamine, tryptamine and tyramine in grass silage. J. Sci. Food Agric. 1962, 13, 29—32.

Sanford, J.: Formation of histamine in ruminal fluid. Nature (Lond.) $1963,199,129-130$.

Shinozaki, K.: Studies on experimental bloat in ruminants. 4. Identification of amines from rumen ingesta and passage of histamine across the rumen epithelium. Tôhoku J. agric. Res. 1957, 8, $149-154$.

Sjaastad, $\emptyset . V .:$ Determination and occurrence of histamine in rumen liquor of sheep. Acta vet. scand. 1967, 8, 50-70.

Sperber, I., S. Hydén \& J. Ekman: The use of polyethylene glycol as a reference substance in the study of ruminant digestion. Ann. roy. agric. Coll. Sweden 1953, 20, 337-344.

Stormorken, H.\& Ø. V. Sjaastad: Diet and histamine in the ruminant. Occurrence of histamine in silage. Arch. int. Pharmacodyn. $1962,140,336-340$.

Tabor, H: \& E. Mosettig: Isolation of acetylhistamine from urine following oral administration of histamine. J. biol. Chem. 1949, 180, 703-706.

\section{SUMMARY}

Histamine ingested with the food or given by mouth disappeared much faster from the rumen than an inert marker (polyethylene glycol), whereas the inactivation of histamine by rumen contents was slow in vitro. This indicated that histamine was absorbed unchanged from the rumen. But when $\mathrm{C}^{14}$-histamine was administered in the 
same way together with carrier, the biological activity disappeared more rapidly from the rumen than the radioactivity, thus indicating transformation of histamine to inactive metabolites. This study gave no clue as to the reason for the apparent discrepancy between the in vitro and the in vivo experiments.

The in vitro inactivation of histamine in rumen contents was related to the time of feeding, the inactivation in rumen contents aspirated just after feeding being considerably slower than in those aspirated about $3 \mathrm{hrs}$. after feeding. By inactivation of histamine by rumen contents, formation of small amounts of conjugated histamine was demonstrated both in vivo and in vitro. In vivo experiments indicated that conjugated histamine was absorbed from rumen.

A small flux of radioactivity into the rumen was demonstrated subsequent to subcutaneous injection of C14-histamine.

\section{ZUSAMMENFASSUNG}

Die Umgestaltung von Histamin an Schafe verabreicht. I. Das Entschwinden aus dem Pansen.

Histamin mit dem Futter eingenommen oder per os verabreicht verschwand viel schneller vom Pansen als ein inerter Referenzsubstanz (Polyäthylenglykol). In vitro verschwand Histamin dagegen sehr langsam vom Pansengehalt. Wurde C14-Histamin jedoch per os zusammen mit einem Carrier gegeben, verschwand die Radioaktivität schneller vom Pansen als die biologische Aktivität. Dieses könnte darauf deuten, dass Histamin in biologisch inaktive Metabolitten umgestaltet wird. Die Untersuchungen gaben keine Erklärung über die scheinbare Nichtübereinstimmung zwischen den in vivo und in vitro Experimenten.

Die Inaktivierung von Histamin im Pansengehalt in vitro zeigte einen Zusammenhang mit dem Zeitpunkt der Fütterung. In Pansengehalt der kurz nach der Fütterung entnommen war, war die Inaktivierung bedeutend geringer als in Pansengehalt, der etwa 3 Stunden nach der Fütterung entnommen war. Bei der Inaktivierung von Histamin im Pansengehalt wurden sowohl in vivo als auch in vitro kleine Mengen von konjugiertem Histamin nachgewiesen. Die in vivo Experimente lassen vermuten, dass konjugiertes Histamin vom Pansen resorbiert wird.

Wo Histamin subkutan gegeben wurde, wurde ein kleiner Strom von Radioaktivität zum Pansen hin festgestellt.

\section{SAMMENDRAG}

Skjebnen til histamin gitt per os til sau. I. Forsvinning fra rumen.

Histamin inntatt med fôret eller gitt per os forsvant mye hurtigere fra rumen enn en inert referansesubstans (Polyetylenglykol). In vitro forsvant histamin derimot langsomt i vominnhold. Dette tydet på at histamin ble absorbert uforandret fra rumen. Men når C14-histamin 
ble gitt per os sammen med carrier, forsvant imidlertid radioaktiviteten hurtigere fra rumen enn den biologiske aktiviteten, noe som tydet på omdannelse av histamin til biologisk inaktive metabolitter. Unders $\varnothing$ kelsene ga ikke noe holdepunkt til å forklare denne tilsynelatende uoverensstemmelse mellom in vivo og in vitro eksperimenter.

Inaktiveringen av histamin $i$ vominnhold in vitro viste relasjon til tidspunktet for fôring. I vominnhold som var aspirert like etter fôring var inaktiveringen betydelig lavere enn $i$ vominnhold aspirert omkring 3 timer etter fôring. Ved inaktivering av histamin i vominnhold ble det påvist dannelse av små mengder konjugert histamin både in vivo og in vitro. In vivo eksperimenter tydet på at konjugert histamin ble resorbert fra rumen.

Når histamin ble gitt subkutant ble det påvist en liten flux av radioaktivitet til rumen.

(Received December 1, 1966). 